http://dx.doi.org/10.12775/szhf.2015.017

PrZEMYSEAW SPRYSZAK

\title{
O „teizmie empirycznym” w Dialogach o religii naturalnej Dawida Hume’a
}

W poniższej pracy rozważam dwa stanowiska, które określam mianem „realizmu empirycznego” oraz ,idealizmu empirycznego" i które w odmienny sposób odnoszę do treści Dialogów o religii naturalnej Dawida Hume’a. Pierwsze z tych stanowisk przypisuję dialogowemu Kleantesowi, obrońcy „teizmu empirycznego", i wykazuję, że właśnie z tak pojmowanego empirycznego realizmu stara się on wyprowadzić wniosek teistyczny. Drugie, które charakteryzuję poniżej, nie zostało w ogóle wzięte w Dialogach pod uwagę, dlatego też zamierzam sprawdzić, czy mimo to nie stanowiłoby dogodniejszej podstawy dla teizmu Kleantesa, dogodniejszej przynajmniej w tej mierze, że uwalniającej uznawany przez niego teizm od części zarzutów sformułowanych przez sceptyka Filona. Na tak postawione pytanie pragnę udzielić odpowiedzi twierdzącej. Ma ona o tyle istotne znaczenie, że pod warunkiem trafności samego ,idealizmu empirycznego”, osłabia słynną krytykę „teizmu empirycznego” dokonaną przez dialogowego sceptyka, którą oczywiście także przytaczam ${ }^{1}$. Niemniej, zwracam pokrótce uwagę także i na problemy, które wynikałyby z akceptacji ,idealizmu empiryczne-

\footnotetext{
${ }^{1}$ Nie rozstrzygam kwestii ważkości owych pozostałych zarzutów, w szczególności nie
} twierdzę, że są one nie do odparcia. 
go” przez zwolennika „teizmu empirycznego”, skoro koncepcja, której nie dosięgają jedne zarzuty, częstokroć bywa narażona na inną, niekiedy nawet surowszą krytykę. Na takiej podstawie staram się ocenić, czy zastąpienie uzasadnienia dostarczanego przez realizm empiryczny uzasadnieniem stanowionym przez idealizm empiryczny byłoby zabiegiem metodologicznie korzystnym z punktu widzenia obrońcy „teizmu empirycznego"2.

${ }^{2}$ Korzystam z klasycznego polskiego wydania: D. Hume, Dialogi o religii naturalnej. Naturalna historia religii, przekł. i wstęp A. Hochfeldowa, PWN, Warszawa 1962. Określenie „teizm empiryczny” pojawia się na początku części V [V, 51], jako odpowiednik zwrotu „experimental theism”; w jedynym ze znaczeń słowo „experiment” było podówczas równoznaczne z „experience”, i w tym znaczeniu Hume używa tego terminu (we współczesnej nam literaturze formułę „experimental theism” w sposób naturalny zastępuje „empirical theism”). Przekład porównuję z tekstem źródłowym podanym w wydaniu pod redakcją D. Coleman: D. Hume, Dialogues Concerning Natural Religion and Other Writings, Cambridge University Press, Cambridge 2007, jak również z komentarzem: W. L. Sessions, Reading Hume’s Dialogues: A Veneration of True Religion, Indiana University Press, Bloomington and Indianapolis 2002, oraz słownikiem: K. R. Merrill, Historical Dictionary of Hume's Philosophy, The Scarecrow Press, Inc., Lanham, Toronto, Plymouth 2008, w sprawie znaczenia słowa „experiment” zob. tamże, s. 135-136. Co do filozoficznego i historycznego milieu rozważań Hume’a, korzystam przede wszystkim ze studium: I. Rivers, Reason, Grace, and Sentiment. A Study of the Language of Religion and Ethics in England 1660-1780, vol. II: Shaftesbury to Hume, Cambridge University Press, Cambridge 2000, w szczególności ze s. 238-321. Zarazem jednak zakładam możliwość idealizacji stanowisk Filona i Kleantesa oraz toczonego przez nich sporu, pomimo znacznej złożoności jego przebiegu, i z niewielkimi wyjątkami pomijam stanowisko trzecie, to znaczy „teizm aprioryczny” głoszony przez Demeę. Przyjmuję ponadto możliwość daleko idącej abstrakcji od kontekstu historycznego, i to zarówno od pierwowzorów rozważanych przez Hume’a stanowisk, którymi jak wiadomo są reprezentatywne dla dwóch głównych odłamów anglikańskiej teologii pierwszej połowy XVIII wieku koncepcje: S. Clarke’a, wyłożona najpełniej w Demonstration of the Being and Attributes of God (1705) i stanowiąca główny pierwowzór dogmatyzmu krótkotrwale bronionego przez Demeę, oraz koncepcja J. Butlera, zawarta w jego Analogy of Religion, Natural and Revealed, to the Constitution and Course of Nature (1736), a która uzyskała w Dialogach postać o wiele obszerniejszych i bodaj bardziej przekonujących wywodów Kleantesa (jakkolwiek nie wyłącznie ona, gdyż w pewnej mierze uwzględniają one także idee należącego do grona "platoników z Cambridge” H. More’a, pomieszczone m.in. w Divine Dialogues, opublikowanych wprawdzie jeszcze w roku 1688, lecz wznowionych w latach 1713 i 1743, jak również poglądy znajdujących się w kręgu I. Newtona: matematyka C. Maclaurina, autora wydanego w roku 1748 An Account of Sir Issac Newton's Philosophical Discoveries, oraz znanego podówczas lekarza, G. Cheyne’a, którego The Philosophical Principles of Religion: Natural and Revealed, ukazały się w roku 1715). Dokonuję ponadto abstrakcji od faktów związanych z osobą samego autora, a więc m.in. od jego respektu dla biskupa Butlera jako myśliciela, o jakim świadczy zarówno kompozycja Traktatu o naturze ludzkiej, jak i postać Dialogów, oraz przeciwnego stosunku do Clarke’a, a także od okoliczności wieloletniego powstawania i opóźnionej publikacji samych Dialogów, ich początkowej recep- 
cji, a wreszcie wysublimowanej (nierzadko jawnie lub skrycie ironicznej) formy samego dzieła, w nieskrywany sposób wzorowanego tyleż pod względem treści, co formy na Cycerońskich dialogach $O$ naturze bogów (i to w tej mierze, że wolno przyjąć, iż Filon przejmuje i udoskonala argumenty dialogowego sceptyka, Kotty). Z tych wszystkich względów pomijam paradoksalne odżegnanie się Filona od dialogowego sceptycyzmu w części XII na rzecz ostrożnej hipotezy "teizmu filozoficznego”, oraz zamykającą Dialogi aprobatę narratora (Pamfila) dla końcowego stanowiska Kleantesa (przypominająca kodę zastosowaną przez Cycerona), a więc zabiegi literackie rodzące nieuchronne i właściwie nadal otwarte pytanie o stanowisko i intencje szkockiego filozofa. Pomimo rozlicznych trudności interpretacyjnych nie jest wykluczone, że celowo zakamuflowane stanowisko filozofa w kwestii religii naturalnej, nie tak negatywne jak w stosunku do religii popularnych (historycznych), stanowiących przedmiot miażdżącej krytyki w Naturalnej historii religii, jest najszczerzej, bez dwuznacznej ironii i teatralnej wzniosłości wyrażone ustami Kleantesa (zob. powyżej) w następującym fragmencie, dodanym, jak pokazują najnowsze badania, już w roku 1757 do zakończenia Dialogów: „Jeżeli cała naturalna teologia, jak zdają się to niektórzy utrzymywać, sprowadza się do jednej prostej, choć nieco wieloznacznej, a w każdym razie nie do określonej tezy, że przyczyna lub przyczyny panującego we wszechświecie (in the universe)porządku pozostają prawdopodobnie w jakiejś dalekiej analogii do ludzkiej in teli g en cj i; jeżeli teza ta nie daje się rozszerzyć, zmienić czy objaśnić w sposób bardziej szczegółowy, jeżeli nie można wywnioskować z niej nic, co by miało znaczenie dla ludzkiego życia lub stanowić mogło źródło jakiegoś działania czy powstrzymania się od działania; i jeżeli analogii tej, choć jest tak niedoskonała, nie można wyprowadzić poza ludzką inteligencję i rozciągnąć z jakimś pozorem prawdopodobieństwa na inne własności umysłu; jeżeli rzecz tak się ma naprawdę - to cóż więcej uczynić może człowiek najbardziej nawet dociekliwy, myślący i bogobojny, jak tezę tę, ilekroć się z nią zetknie, jasno filozoficznie zaakceptować (give a plain, philosophical assent to the proposition, as often as it occurs) i wierzyć, że argumenty, na których się zasadza, przeważają nad zarzutami, które przeciw niej przemawiają?” [XII, 134-135, zob. także swoistą antycypację tej sugestii we fragmencie III, 39]. Oczywiście dodatek ten nie zamyka dyskusji nad ostatecznym stanowiskiem Hume’a odnośnie do istnienia Boga osobowego, skoro na podstawie analizy całości spuścizny filozofa, uwzględniającej także wypowiedzi prywatne, można przedłożyć zarówno argumenty za przypisaniem mu ostrożnego, filozoficznego teizmu, nie implikującego ani dogmatów określonej religii, czy jakichkolwiek zaleceń moralnych, ani nie pociągającego tezy, iż może on (ów hipotetyczny teizm) uzyskać postać trwałego, regulującego życie przeświadczenia. Współcześnie starają się w rozmaity sposób przypisać Hume’owi to stanowisko, niejednakowo zresztą pojmując je w szczegółach, między innymi C. Hendel, J. Wieland, N. Capaldi, T. Penelhum, S. Andre oraz T. S. Yoder (już wcześniej uczynił to m.in. biograf filozofa, J. H. Burton, a także D. Stewart). Inni badacze optują natomiast (i to w większości), za przypisaniem Hume'owi indyferentyzmu albo sceptycyzmu, czy to radykalnego, którego Filon jest wyrazicielem przez większą część Dialogów, czy też zmitygowanego, uznającego wprawdzie zasadność konsekwentnego sceptycyzmu, aczkolwiek wyrazicielem świadomym praktycznej nieskuteczności takiej konsekwencji wobec siły i kierunku naturalnych przekonań (z uwagami jak powyżej: N. Kemp Smith, E. C. Mossner, R. H. Hurlbutt, J. V. Price, J. Noxon, R. J. S. Manning, J. C. A. Gaskin, S. Tweyman, B. Logan, 
Mówiąc najogólniej, jakkolwiek w sposób niewątpliwie zrozumiały dla czytelnika Dialogów określeniem ,realizm empiryczny” można objąć te założenia dotyczące świata jako całości, które akceptuje Filon w sporze prowadzonym z Kleantesem, to znaczy akceptuje na potrzeby dyskusji, i co do których zakłada, iż są aprobowane przez Kleantesa, a przynajmniej, że powinny być przez niego akceptowane pod groźbą niedopuszczalnej wedle empirysty niezgodności teorii z doświadczeniem ${ }^{3}$. Treść Dialogów pokazuje dostatecznie wyraźnie, że sceptyk, personifikowany przez Filona, usiłuje wykazać, iż obraz świata potwierdzany przez doświadczenie zmysłowe, a zatem obraz, na który chociażby w ostateczności, pod wpływem krytycznego namysłu powinien się zgodzić także i jego współrozmówca, z założenia przywiązujący wagę do wskazań płynących ze zmysłów, nie uprawomocnia wniosku teistycznego, głoszącego istnienie Boga rozumianego jako pierwotna, doskonała, nieskończona, absolutnie dobra, bezcielesna i inteligentna przyczyna świata jako całości.

Pobieżną charakterystykę tego realizmu należałoby jednak uszczegółowić, a więc zrekonstruować ów aposterioryczny obraz świata, założony w wypowiedziach Filona skierowanych do Kleantesa. Wydaje się zatem, że Filon przyjmuje następujące założenia:

T1) W doświadczeniach zmysłowych dany nam jest świat genetycznie i aktualnie niezależny od tych doświadczeń [II, 34]; nic nie wskazuje w sposobie, w jaki się wypowiada Filon, aby uważał on esse przedmiotów należących do świata za

D. O’Connor, i wielu innych, oczywiście również i taki pogląd głoszono wcześniej, czynił tak chociażby T. Reid). Padają ponadto argumenty za dopatrzeniem się z konieczności złagodzonego lub zakamuflowanego ateizmu (z analogicznymi zastrzeżeniami: A. J. Ayer, B. S. Cordry, z grona polskich badaczy - A. Hochfeldowa oraz L. Kołakowski), a nawet braku jednoznacznego stanowiska (J. Laird, W. L. Sessions). Dla zwięzłości tu i poniżej z niewielkimi wyjątkami odnoszę się tylko do polskiego wydania Dialogów, skracam opis bibliograficzny do cyfry rzymskiej, oznaczającej odpowiednią część, oraz do numeru strony, zamkniętych w nawiasie klamrowym. Tam, gdzie wydaje się to możliwe, a zarazem dogodne dla czytelnika, umieszczam tego rodzaju opis już w tekście głównym i rezygnuję z przytaczania treści verbatim. Opis bibliograficzny tych prac wspomnianych powyżej autorów, na które zwróciłbym szczególną uwagę, z analogicznych powodów podaję jedynie w Bibliografii. Natomiast twierdzenia, które pragnę uwyraźnić, numeruję i wyodrębniam.

${ }^{3}$ Mam więc na myśli zarówno dokonaną przez Filona rekonstrukcję argumentu Kleantesa [II, 23], jak i krytykę, którą do niej dołącza [II, 27-35]. Co istotne, Kleantes zgadza się ze sposobem, w jaki jego argument został zrekonstruowany [II, 28], jakkolwiek rzecz jasna nie na krytykę. 
równe percipi, lub by ontologiczny status tych przedmiotów wzbudzał w jego przekonaniu zasadnicze wątpliwości.

T2) Doświadczenie tego świata jest wiarygodne, to znaczy zazwyczaj wystarczająco odpowiada przedmiotom niezależnym od doświadczenia (które na użytek poniższych rozważań można by nazwać „zewnętrznymi”); Filon nie czyni wszakże przedmiotem dyskusji sposobu, w jaki funkcjonuje nasza zmysłowość, nie zwraca także uwagi Kleantesa na możliwość złudzeń zmysłowych, skądinąd istotną właśnie dla sceptyka, a tym bardziej na zrozumiałą dla pirrończyka trudność w odróżnieniu doświadczeń wiarygodnych od niewiarygodnych $^{4}$. Przeciwnie, polega w całej rozciągłości na zmysłach i zakłada, że przedmioty mają tego rodzaju budowę i taką jakościową charakterystykę, jaka jest dostępna naszemu doświadczeniu.

T3) Przedmiotem doświadczeń zmysłowych są: a) psychofizyczne indywidua, wśród których znajduje się podmiot doświadczenia, potrafiący działać w sposób rozumny i celowy, b) wytwory rozumnych i celowych działań takich podmiotów, stanowiące realizację wcześniej przyjętego planu i na ogół służące do uzyskania zamierzonego celu (przedmioty te na potrzeby niniejszych rozważań możemy nazwać „,artefaktami”, a niektóre z artefaktów - stosowanym w samych Dialogach mianem „maszyn”), c) mnogość różnego rodzaju przedmiotów, których budowa oraz organizacja części zdradza dostosowanie środków do celów (będą to oczywiście organizmy zwierząt i roślin), d) przedmioty nieożywione, w całej rozmaitości rodzajów oraz wielości form charakteryzujących materię.

Filon zwraca uwagę Kleantesa, że doświadczenie w równym stopniu uzasadnia również i poniższe stwierdzenia:

T4) Pod względem chronologii, liczebności oraz rozmaitości rodzajów artefakty znacznie ustępują znanym $\mathrm{z}$ doświadczenia organizmom roślinnym i zwierzęcym [II, 29-31].

T5) Nie wszystkie przedmioty należące do świata są, były lub będą przedmiotami doświadczeń.

T6) Nie był (i oczywiście tym bardziej nie może być) przedmiotem doświadczenia zmysłowego początek świata, jeżeli taki początek w ogóle zaistniał [II, 31-32].

${ }^{4}$ Tę trudność podnosi natomiast nie dowierzający zmysłom Demea we fragmencie dodanym przez Hume’a w rękopisie do pierwotnego tekstu dzieła [III, 41-42]. 
T7) Nie są ponadto przedmiotami doświadczenia światy alternatywne, podobne do spostrzeganego świata, zwłaszcza światy ewentualnie poprzedzające świat fragmentarycznie udostępniany przez doświadczenie zmysłowe [II, 32, 35].

Przyjmijmy zatem, że przez „empiryczny realizm” rozumieć będziemy twierdzenia T1)-T7). Biorąc pod uwagę treść tych twierdzeń, tego rodzaju nazewnictwo wcale nie wydaje się nieuprawnione. Nietrudno ponadto dostrzec, że tak pojmowany „empiryczny realizm” stanowi naturalną przesłankę dowodu teleologicznego, a więc i jego historycznych postaci ${ }^{5}$.

${ }^{5}$ Także taki lub podobny realizm stanowi podstawę wywodu rozpoczętego przez stoika Balbusa na początku drugiej księgi literackiego pierwowzoru Dialogów: „Bo kiedy spoglądamy na niebo i przypatrujemy się ciałom niebieskim, cóż może być dla nas bardziej jasne i oczywiste niż to, że istnieje jakaś potęga o najwyższym rozumie, która tym wszystkim rządzi? [...] Jeśli ktoś ma tu wątpliwości, to nie pojmuję, dlaczego nie miałby być niepewnym także istnienia albo nieistnienia słońca. Czyż bowiem to jest bardziej oczywiste niż tamto?” (M. T. Cicero, O naturze bogów. O wróżbiarstwie. O przeznaczeniu, przeł. W. Kornatowski, PWN, Warszawa 1960, s. 75-76). Realizm zarówno w O naturze bogów, jak i Dialogach, jest w sposób naturalny usprawiedliwiony względami historycznymi, to znaczy realizmem systemów filozofii starogreckiej, w których przynajmniej od czasów Anaksagorasa z obiektywnie istniejącego, poznawanego porządku i ładu wnoszono o istnieniu inteligentnej przyczyny albo pewnej mnogości przyczyn, przeciwstawianej czystemu przypadkowi. Realizm przyjmuje również Butler w Analogii, do której Dialogi odnoszą się z pewnością w nie mniejszym stopniu, przy czym dokonuje ważnej i daleko idącej zmiany, zgodnie z którą uporządkowanie obserwowane w świecie przemawia za prawdopodobieństwem nie samej ogólnej tezy o istnieniu jakiejś inteligentnej przyczyny świata, co o chociażby nieznacznym prawdopodobieństwie religii chrześcijańskiej, głoszącej przecież nie tylko istnienie inteligentnej przyczyny świata, ale i np. wcielenie Boga oraz życie wieczne. Warto zaznaczyć, że tak właśnie przedstawia się polemika prowadzona $\mathrm{z}$ kolei przez samego Butlera $-\mathrm{z}$ deizmem M. Tindala (Christianity as Old as the Creation, ósme wydanie w r. 1730) i A. Collinsa (A Vindication of the Divine Attributes, 1710), oraz aprioryzmem Clarke’a (dz. cyt.). Na podkreślenie zasługuje ponadto, że myśliciel ten - wzorem J. Locke’a - zdawał sobie sprawę z ograniczeń ludzkiej wiedzy, i dlatego prawami analogii powiązał chrześcijaństwo nie tyle z porządkiem istniejącym w świecie ponad wszelką wątpliwość, ile z porządkiem jawiącym się nam w świecie dzięki zmysłowości. Realistyczną przesłankę tym bardziej przyjmują dwudziestowieczni obrońcy argumentu z celowości, na przykład R. Swinburne, świadomie nawiązujący do rozważań Butlera (ale także do „piątej drogi” Tomasza z Akwinu i dowodu a contingentia mundi G. W. Leibniza). Zob. przede wszystkim "The Argument from Design”, „Philosophy”, vol. 43, no. 143, 1968, s. 199-212, w której twierdzi, że krytyka Hume’a wychodzi z błędnych założeń metodologicznych i że nie dotyczy bardziej wyszukanego argumentu, w którym bierze się wzgląd nie tyle na budowę czy ułożenie przedmiotów w świecie, ile na porządek następstwa rzeczy bądź zdarzeń, dla którego jedynym jak dotąd metodologicznie uprawnionym wyjaśnieniem jest uznanie realności inteligentnej, oso- 
Należy zauważyć, że Kleantes w żadnej ze swoich wypowiedzi, skierowanych czy to do Filona, czy do Demei, nie przeczy tezom T1)-T3), ani nie podważa twierdzeń T4)-T7), traktowanych powyżej jako niezbędne i równoprawne uzupełnienie empirycznego obrazu świata. Kością niezgody staje się natomiast to, czy na podstawie przesłanek, na jakie zgadzają się obydwaj dyskutanci i odnośnie do których nie ma między nimi zasadniczych rozbieżności, wolno na drodze analogii wysnuć wniosek wyprowadzany przez Kleantesa. Teista sądzi bowiem, że przyjmowane w dyskusji założenia $\mathrm{w}$ istocie umożliwiają akceptację wspomnianej już tezy:

T8) Przyczyną obserwowanego świata jako całości, zawierającego w sobie mnogość przedmiotów zdradzających uporządkowanie i ład, jest Bóg, pojęty jako przedmiot analogiczny do naszego umysłu, tyle że doskonały, bezcielesny oraz obdarzony inteligencją [II, 23, III, 34-40]. Tak bowiem jak niewątpliwego przykładu artefaktu będącego dziełem ludzkiego intelektu dostarcza dom, statek, albo mechanizm zegara, tak dobitnym przykładem artefaktu stanowiącego analogicznie - dzieło inteligentnej przyczyny jest dowolny organizm roślinny lub zwierzęcy, a przez to świat rozumiany jako całość, której takie artefakty (lub maszyny) są elementami, czy wręcz pojmowany jako jedna maszyna, złożona $\mathrm{z}$ nieprzebranej mnogości takich maszyn [II, 23, XII, 120].

Wolno zatem przyjąć, że przesłanki T1)-T7), opisujące ów zmysłowo doświadczany świat, stanowią w przekonaniu Kleantesa wystarczającą i trwałą podstawę dla teistycznego wniosku T8) i że ten wniosek, nie zaś przesłanki,

bowej przyczyny. Idee te rozwijał Swinburne w kolejnych pracach, zwłaszcza w The Existence of God, Clarendon Press, Oxford 2004. Uwypuklenie tych wszystkich historycznych zależności i prawidłowości nie dowodzi rzecz jasna, że realizm nie mógłby zawierać przesłanki mówiącej o złożoności procedur poznawczych ujawniających ów ład i uporządkowanie, a zwłaszcza o konieczności prowadzenia w tym celu dedukcyjnych bądź indukcyjnych wnioskowań (ewentualnie wnioskowań, za którymi optowała przywołana tradycja, więc właśnie per analogiam). Zresztą same Dialogi dotyczą „religii naturalnej” przecież i w tym, brzmiącym nowocześnie znaczeniu, w którym jej tezy miałyby być wynikiem naukowego (zwłaszcza eksperymentalnego i matematycznego) badania przyrody, prowadzącego w szczególnych przypadkach do odkryć na miarę dokonań Galileusza czy I. Newtona, a dla Hume’a niewątpliwie również do jego własnych ustaleń, dotyczących natury ludzkiej i będących realizacją naturalistycznego programu przyjętego w Traktacie. Za próbę realizacji tego planu w odniesieniu do fenomenu religii należałoby przy tym uważać nie tyle Dialogi, badające ewentualne racje stanowiska teistycznego, ile dociekającą faktycznych przyczyn przekonań religijnych Naturalna historię religii. 
ma zamiar uchylić sceptyczny współrozmówca. Przesłanki te wraz z wnioskiem stanowią „empiryczny teizm” skrytykowany w Dialogach.

Filon twierdzi natomiast, że opis świata przyznający wagę świadectwu doświadczenia zmysłowego oraz sugestii, że doświadczenie to podlega wspomnianemu powyżej ograniczeniu, którego Kleantes jako empirysta także nie powinien negować, bynajmniej nie usprawiedliwia teistycznej konkluzji T8) - być może nie znajduje się z nią w sprzeczności, lecz bynajmniej jej nie uzasadnia. Filon przedkłada takie oto argumenty:

T9) Rozumowanie Kleantesa, nawet gdyby było poprawne pod względem przesłanek i miało stanowić przykład rozumowania przez analogię, prowadziłoby w sposób bardziej uprawniony do wniosków jawnie odmiennych od twierdzenia T8), takich jak te, zgodnie z którymi a) przyczyną świata jest albo psychofizyczne indywiduum, a więc połączenie ciała i umysłu, nie zaś bezcielesny umysł [VI, 59-61], albo wręcz przedmiot materialny [VIII, 79-80], b) czynnością stwarzającą świat nie jest akt rozumu, czyli inteligencja, lecz któryś ze sposobów kreacji bardziej rozpowszechnionych w świecie zmysłowym [VI, 6572], wobec czego należałoby raczej przypuszczać, że c) przyczyna świata, o ile w ogóle istnieje [VIII, 74-78], nie jest jedyna, jak twierdzi teista [IV, 54-57, VI, 65], ani d) nie odznacza się najwyższym z możliwych stopni doskonałości (ani nieskończonością lub absolutną dobrocią) [IV, 53-54, 57, X, 88-100, XI, 102114]. Rozumowanie przez analogię, którym posługuje się teista empiryczny, jest niepoprawne, albowiem zasadza się na przyjęciu, że istnieje odpowiedniość między rozumną przyczyną dzieła rąk ludzkich a przyczyną dowolnego elementu natury, którego budowa zdradza wzajemne dostosowanie części umożliwiające działanie odbywające się w pewnym celu, tymczasem domniemanie, że taka analogia zachodzi, okazuje się bezpodstawne w świetle twierdzeń T4)-T7) [VI, 66-68]. Błąd Kleantesa polega na zbagatelizowaniu faktu, że w rozumowaniu przechodzi on od charakterystyki ułamkowej części do charakterystyki nieporównanie większej całości [IV, 53], a także na przeoczeniu zasady, zgodnie z którą na podstawie obserwacji skutku domniemanej przyczynie wolno przypisać nie więcej niż to, co potrzebne do wywołania tego skutku [V, 53-54 $]^{6}$.

${ }^{6}$ Ta ostatnia zasada stanowi główny argument przeciw teizmowi empirycznemu wysuwany w Badaniach dotyczacych rozumu ludzkiego. Zobacz oczywiście D. Hume, Badania dotyczace rozumu ludzkiego, przeł. J. Łukasiewicz i K. Twardowski, PWN, Warszawa 1977, s. 161-180, tzn. esej O szczególnej opatrzności i o życiu przyszłym (początkowo zatytułowany: O konsekwencjach praktycznych religii naturalnej), stanowiący pierwotnie jedną z nieopublikowanych przez wzgląd na Butlera oraz z obawy o reakcję konserwatywnego duchowieństwa - części Traktatu. Zasada ta ma czynić wnioskowanie przyczyn ze skutków dedukcyjnie poprawnym, a samo zwrócenie na nią uwagi prowadzi do wniosku, że dowodzący istnienia Boga na pod- 
Im jednak bardziej są one niewspółmierne, tym bardziej odległa analogia i tym słabiej uzasadniony wniosek; im natomiast bardziej współmierne są część oraz całość, tym bardziej odbiega konkluzja od teistycznego wniosku T8).

T10) Poprawne rozumowanie przez analogię zastosowane do świata jako całości oraz do jego przyczyny musiałoby uwzględnić dodatkowe przesłanki T4)-T7) i polegać na przyjęciu, i to na podstawie świadectwa doświadczenia, a nie apriorycznych spekulacji, że światy podobne do spostrzeganego przez nas są tworzone przez jedną, doskonałą, inteligentną i bezcielesną przyczynę; przesłanki tego rozumowania w oczywisty sposób nie są i nie mogą być zasadne właśnie w świetle stanowiących inaczej tez T6) i T7), które konsekwentny empirysta powinien zaakceptować [II, 32, 35].

T11) Teizm empiryczny nie umożliwia rzetelnego wyjaśnienia początku świata, albowiem prawa rządzące myślą nie są bardziej znane od praw rządzących przedmiotami materialnymi, i nawet jeżeli ów teizm nie musiałby być uzupełniony o teorię wskazującą na przyczynę praw rządzących każdym inteligentnym działaniem, to i tak ustępowałby pod względem prostoty przypuszczeniu, iż obserwowane w świecie na tysiącach przykładów ład i uporządkowanie są wynikiem praw z natury przysługujących już samej materii, a nie różnemu od niej duchowi. Przeciwnik teizmu, zamiast przyporządkowywać światu bezcielesną przyczynę działającą w bliżej nieokreślony sposób, może przypisać równie nieznaną zdolność do samoorganizacji bezpośrednio światu materialnemu i uznać przynależenie doń tej zdolności za fakt nie podlegający już dalszemu wyjaśnieniu [IV, 47-49].

stawie ładu i uporządkowania nieświadomie dowodzą co najwyżej istnienia przyczyny niejako proporcjonalnej do obserwowanych skutków, a więc nie tak doskonałej, jak Bóg, o jakim miałoby pouczać Objawienie. Na zasadę tę w podobny sposób powołał się później m.in. I. Kant w przedsięwziętej krytyce dowodu fizyko-teologicznego (I. Kant, Krytyka czystego rozumu, przeł. R. Ingarden, Wydawnictwo Antyk, Kęty 2001, A 620-A 631, s. 488-494). Mimo wszystko wolno jednak zgłaszać zastrzeżenia co do prawdziwości takiej przesłanki, albowiem oznacza ona, że skoro przyczynie wolno przypisać jedynie to, co konieczne do wywołania zaobserwowanego skutku, nader ułamkowa część dokonywanych przez nas wnioskowań odznaczałaby się metodologiczną poprawnością, a poprawne hipotezy dotyczące przyczyn charakteryzowałyby się niewielką liczbą empirycznie sprawdzalnych konsekwencji. Sam Kant, ponownie idąc za Hume'm, dostrzega w dowodzie z celowego zamysłu błędne dążenie do wyjaśnienia zjawisk tym, co niewyjaśnione (zob. dz. cyt., A 772-A 773, s. 574-575). Podejrzewam jednak, że tytułem odpowiedzi wolno ponowić zastrzeżenie zasugerowane powyżej. 
Pokrótce scharakteryzuję zatem zapowiedziane stanowisko ,idealizmu empirycznego". Przyjmuję mianowicie, że składają się na nie następujące twierdzenia:

T12) W doświadczeniach zmysłowych dana jest nam mnogość wrażeń zmysłowych, takich jak wrażenia barw, zapachów czy smaków, lecz tylko niektóre spośród takich wrażeń genetycznie i aktualnie zależą od tych doświadczeń, ewentualnie od aktów woli doświadczającego (nawet jeżeli zależność ta polega jedynie na obserwowanym następstwie i związanym z nim przyzwyczajeniu).

T13) Doświadczenie tych wrażeń może być w tym znaczeniu wiarygodne, że jest logicznie lub epistemicznie możliwe, że wystarczająco odpowiada ono przedmiotom niezależnym od doświadczenia (które na użytek poniższych rozważań nazwaliśmy „,zewnętrznymi”).

T14) Jest w tym znaczeniu niewykluczone również i to, że przedmiotami doświadczeń zmysłowych, danymi wraz z wrażeniami lub przez te wrażenia, są: a) psychofizyczne indywidua, wśród których znajduje się podmiot doświadczenia, b) wytwory świadomych działań takich indywiduów, stanowiące realizację wcześniej powziętego planu i na ogół służące do uzyskania pewnego celu (a więc artefakty, a w szczególności maszyny), c) różnego rodzaju przedmioty, których budowa oraz organizacja części zdradza dostosowanie środków do celów (organizmy roślinne i zwierzęce), d) przedmioty nieożywione, stanowiące rozmaitość rodzajów i form świata materialnego.

T15) Podobnie, jest tak samo (w tym znaczeniu) możliwe, że pod względem liczebności i rozmaitości rodzajów artefakty znacznie ustępują znanym z doświadczenia organizmom roślinnym i zwierzęcym.

T16) Jest tak samo możliwe, że nie wszystkie przedmioty należące do świata są, były lub będą przedmiotami doświadczeń.

T17) Jest możliwe i to, że nie był (i oczywiście tym bardziej nie może być) przedmiotem doświadczenia ani początek świata, jeżeli taki początek w ogóle zaistniał,

T18) ani światy alternatywne, podobne do spostrzeganego przez nas świata.

„Idealizm empiryczny” stwierdza zatem istnienie wrażeń, ale nie stwierdza istnienia przedmiotów zewnętrznych $\mathrm{w}$ tym znaczeniu, $\mathrm{w}$ jakim rozumie je ,realizm empiryczny” i jakkolwiek ich istnienia tak samo nie wyklucza, 
będzie (lub byłby) prawdziwy nawet wtedy, gdyby przedmioty zewnętrzne w ogóle nie istniały, lecz były jedynie logicznie bądź epistemicznie możliwe.

Tak pojęty idealizm empiryczny nie stanowi zatem dokładnego przeciwieństwa empirycznego realizmu, to znaczy nie wyklucza się z nim, przybiera raczej postać koncepcji bardziej ostrożnej z logicznego punktu widzenia $^{7}$. Nietrudno obydwóm stanowiskom nadać takie sformułowanie, dzięki któremu okaże się, że realizm empiryczny pociąga za sobą tak pojęty idealizm empiryczny, oraz że przy założeniu, że ani logiczna, ani epistemiczna możliwość nie implikują faktyczności, nie wystąpi relacja odwrotna. Płynie stąd wniosek, że zastąpienie pierwszego ,empiryzmu” przez drugi, ewentualnie dokonane przez obrońcę teizmu empirycznego, sprowadzałoby się de facto do odpowiedniego osłabienia stanowiska realizmu empirycznego, a ściślej, do uchylenia twierdzeń dotyczących spostrzegalności przedmiotów zewnętrznych oraz do zastąpienia ich odpowiednimi twierdzeniami dotyczącymi wrażeń oraz możliwości, że przez wrażenia spostrzega się również przedmioty zewnętrzne. Stanowisko nazywane powyżej ,,idealizmem empirycznym" przypomina zatem postawę zalecaną przez klasyczny sceptycyzm, którą sam Filon, jako sceptyk, powinien uznawać za własną, co w obliczu zadania, przed którym staje Kleantes bynajmniej nie musi uchodzić za wadę. Krytyka Filona stałaby się z pewnością mniej przekonującą, gdyby już z założeń pokrewnych sceptycyzmowi udało się wysnuć wniosek teistyczny ${ }^{8}$.

Spróbujmy wobec tego wyprowadzić wniosek teistyczny z przesłanek idealistycznych, nie zapominając o konieczności zastosowania rozumowania przez analogię, skoro to właśnie ona ma łączyć teizm ze świadectwem

${ }^{7}$ Zwróćmy przede wszystkim uwagę, że jeżeli tylko przez owe „wrażenia” nie będzie się rozumieć ani tych uczuć, które Hume określa mianem "gwałtownych”, ani zależnych od takich uczuć wyobrażeń, wspomniane stanowisko nie będzie dostarczać ani psychologicznej, ani logicznej podstawy dla krytykowanych przezeń postaw zabobonu i egzaltacji („entuzjazmu”), stanowiących jego zdaniem rozpowszechnione i zgubne w skutkach przeciwieństwo „prawdziwego teizmu” lub „prawdziwej religii”. W sprawie obydwu postaw zob. [XII, 127-130], tudzież esej $O$ zabobonie i egzaltacji, [w:] D. Hume, Eseje z dziedziny moralności i literatury, przeł. T. Tatarkiewiczowa, PWN, Warszawa 1955, s. 28-33.

${ }^{8}$ Nie jest to jednakże stanowisko tożsame z klasycznym, czyli pirrońskim sceptycyzmem, skoro dogmatycznie stwierdzając istnienie obiektywnej (logicznej lub epistemicznej) możliwości istnienia przedmiotów zewnętrznych, i to dość charakterystycznie rozumianych, poprzestaje na konstatacji zachodzenia subiektywnego, zwłaszcza bezwiednie się narzucającego, doraźnego poczucia takiej możliwości. Można zatem powiedzieć, że obiektywna możliwość stanowi korelat w i a r y g o d n e g o poczucia możliwości i że idealizm empiryczny uznaje wiarygodność jednego z takich poczuć. 
empirii. Jeżeli uwzględni się wątpliwości zgłoszone przez samego Hume'a odnośnie do doświadczeniowej uchwytności związku przyczynowego, wnioskowanie przebiegnie w sposób następujący:

T19) Obserwujemy w sobie, że wiele wrażeń zmysłowych danych nam w doświadczeniu zależy od czegoś, co zwykle oznaczamy mianem „naszej woli”, to znaczy pojawiają się one jeżeli nie pod wpływem, to chociażby w następstwie stanów czy czynności, które zazwyczaj określamy mianem „świadomych decyzji” albo „uprzytamnianych zamiarów”; niejednokrotnie mogę na przykład znaleźć się w sytuacji, że nie doznaję już wrażenia zieleni, lecz tylko wrażenie czerwieni. Istnieją w naszej świadomości jednak i takie wrażenia, podobne do tamtych i nierzadko najwyraźniej tego samego rodzaju, co one, w których przypadku nie obserwujemy podobnej zależności, czyli nie doświadczamy wyraźnego związku między naszymi postanowieniami czy zamiarami a pojawieniem się i trwaniem tych wrażeń w naszej jaźni, nawet jeżeli ten związek miałby polegać tylko na obserwowanym następstwie. Co więcej, pewien stopień takiej niezależności znajduje wyraz wręcz w dowolnej naszej decyzji czy zamiarze: mogę bowiem co prawda sprawić, odpowiednio kierując spojrzenie, że nie spostrzegam zieleni, tylko czerwień, lecz przecież nie leży w mej gestii zastąpienie pierwszego $\mathrm{z}$ tych wrażeń dowolnym innym wrażeniem; to pomiędzy czym wybieram, w taki czy inny sposób kierując swoim aktem, przeważnie jest mi już dane, wchodzi w skład zbioru możliwości niezależnego od mojego świadomego ustanowienia. Ponieważ zasady rozumowania przez analogię, nie będące przedmiotem sporu, każą przyjąć, że podobne przedmioty wymagają podobnych przyczyn, mamy prawo domniemywać, że wrażenia w tej mierze, w jakiej są niezależne od nas, zależą od woli bądź decyzji innego podmiotu (i to nawet jeżeli doświadczane sprawstwo miałoby polegać na następstwie zdarzeń oraz na powiązanym z nim, nawykowym oczekiwaniu).

T20) Wrażenia zależne od nas nierzadko noszą znamiona uporządkowania i ładu, co do których mamy prawo domniemywać, że są dziełem tego czynnika w nas samych, który przeważnie określamy mianem „inteligencji” albo „rozumu". Pomimo ograniczeń, jakim doznawanie podlega i o których była mowa powyżej, potrafimy wszakże doznawać wrażeń w określonym, wybranym przez siebie porząaku, odmiennym od gry przypadku. Odpowiednio kierując własnym spostrzeżeniem, jesteśmy na przykład w stanie sprawić (chociażby w ograniczonym, jak poprzednio, znaczeniu słowa „sprawstwo"), iż doznajemy na przemian wrażeń czterech barw, a więc każde wrażenie barwne pojawia się regularnie jedno po drugim, nawet jeżeli te pojawiające się wrażenia miałyby nie być dokładnie tymi samymi wrażeniami, które pojawiły się wcześniej, lecz wrażeniami tego samego rodzaju. Ponieważ jednak takim ładem czy regular- 
nością odznaczają się również owe wrażenia niezależne od woli, a nawet uporządkowanie i ład są w ich przypadku nieporównanie większe, na tyle duże, że potrafię wrażenia te uporządkować, nadając ich złożeniom osobne nazwy i będąc w stanie przewidywać ich pojawienie się w mojej świadomości, przyczyna każdego takiego wrażenia analogicznie odznacza się inteligencją lub rozumem, i to nawet w stopniu znacznie przekraczającym zdolności mego umysłu.

T21) Ponieważ ja sam stanowię jeden podmiot, to znaczy nie dostrzegam w sobie następstwa różnych podmiotów, ani równoczesności odmiennych „ja”, mam prawo wnosić per analogiam, że wrażenie dane mi w doświadczeniu zmysłowym i niezależne ode mnie zależy od jednego podmiotu, nie zaś od ich wielości.

W ten oto sposób tezy T19)-T21) najwyraźniej oznaczają (na zasadzie analogii) istnienie jednego i tylko jednego podmiotu, obdarzonego rozumem

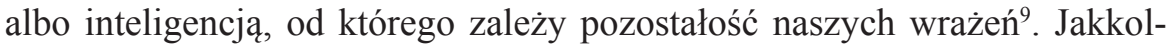

9 Tego rodzaju rozumowanie oczywiście przywodzi na myśl koncepcje filozofów dostrzegających problematyczność istnienia świata materialnego, lecz skłonnych zarazem dowodzić istnienia Boga także za pomocą rozumowania a posteriori; a więc w szczególności Descartesa, Malebranche’a oraz Berkeleya. Zarysowują się jednakże istotne i niejednakowe różnice między sugerowanym powyżej „idealizmem empirycznym”, zwłaszcza uwzględniającym ewentualne zastrzeżenia dotyczące związku przyczynowego, a argumentami przedłożonymi przez wspomnianych filozofów. Po pierwsze, Kartezjusz i Malebranche niewątpliwie cenili wyżej dowody a priori nad a posteriori, przy czym pierwszy wnosił o istnieniu Boga z idei Boga nie będącej wrażeniem zmysłowym, ową „mętną odmianą myślenia”, natomiast drugi, głosząc radykalny okazjonalizm, podał w wątpliwość zastosowaną powyżej przesłankę dotyczącą sprawstwa naszego umysłu w odniesieniu do niektórych wrażeń zmysłowych; okazjonalizm taki stał się zresztą, jak wiadomo, przedmiotem krytyki Hume'a w Badaniach dotyczących rozumu ludzkiego (zob. dz. cyt., s. 86-89). Idealizm empiryczny byłby przypuszczalnie bliższy stanowisku Berkeleya, tyle tylko, że filozof ten w Traktacie właśnie odrzucił nawet hipotetyczną możliwość istnienia przedmiotów materialnych pojmowanych jako przedmioty niemyślące i odmienne od wrażeń zmysłowych, natomiast na użytek Próby stworzenia nowej teorii widzenia akceptował realistyczną przesłankę. Po drugie, zachodzi wątpliwość, czy myśliciele ci uznaliby argument zasadzający się już nawet nie na indukcji, co na samej tylko analogii. Jakkolwiek zabrzmi paradoksalnie, najbardziej podobny do wspomnianej argumentacji wydaje się Locke'owski dowód na istnienie Boga, wykazujący istnienie Boga jako istoty ze swej natury myślącej, na podstawie treści naszego doświadczenia w e w n ęt r z n e g o , to znaczy tego porządku, jakim odznaczają się idee stanowiące nasze myślenie. Poprawność takiego dowodu zdaniem Locke’a nie zależy od tego, czy to dane w refleksji myślenie odbywa się w substancji materialnej, czy niematerialnej. Porównaj oczywiście J. Locke, Rozważania dotyczace rozumu ludzkiego, przeł. B. Gawecki, PWN, Warszawa 1955, t. 2, ks. IV, rozdz. 10 (s. 336-353). Co do ewentualnego podobieństwa do stanowiska uwzględnianego w takim czy innym stopniu w sa- 
wiek stanowisko, na które składają się tezy T13)-T22), można przypuszczalnie uznać za pewną postać „teizmu empirycznego”, nie zostało ono wzięte pod uwagę w Dialogach.

Oczywiście należałoby w pierwszej kolejności sprawdzić, czy powyżej zarysowane rozumowanie nie stanie się przedmiotem zarzutów pomieszczonych w tezach T9)-T11). Twierdzę, że pod tym względem idealizm empiryczny ma przewagę nad realizmem empirycznym, albowiem jest on narażony jedynie na część zarzutów zawierających się w tezie T9), a zarazem nie dotyczy go ani zarzut T10), ani T11) ${ }^{10}$.

W przypadku zarzutów uwzględnionych w tezie T9), zachodzi wyraźna różnica między realizmem empirycznym a empirycznym idealizmem. Pierwsze $\mathrm{z}$ tych stanowisk stawia teistę $\mathrm{w}$ położeniu, w którym na podstawie znanej mu części świata, czyli tej części, która zawiera artefakty oraz rozliczne przedmioty zdradzające uporządkowanie i cel, wnosi o przyczynie świata jako całości. Sceptyk ma prawo wysunąć zarzut - i Filon faktycznie tak czyni - że na podstawie własności części, i to części niewielkiej, do której ogranicza się nasza empiryczna wiedza o świecie, wnosi się o przyczynie całości

mych Dialogach, dość przywołać niekoniecznie retoryczne pytanie Kleantesa: „Zastanów się nad okiem, przeanalizuj je; przyjrzyj się jego budowie i kunsztownemu urządzeniu i powiedz mi wedle tego, co sam czujesz (from your own feeling), czy idea kogoś, kto wszystko to obmyślił, nie narzuci ci się natychmiast $z$ siła zmysłowego wrażenia? (with a force like that of sensation?)" [III, 39; kursywę podaję zgodnie z tekstem oryginalnym]. Warto zauważyć, że dokładniejsze badanie wskazuje, że passus ten stanowi niemal dosłowny i skądinąd nie jedyny cytat z referującej myśl Newtona rozprawy An Account... C. Maclaurina (w tej sprawie zob. R. H. Hurlbutt, David Hume and Scientific Theism, „The Journal of the History of Ideas”, vol. 17, no, 4, 1956, s. 492). Nie zmienia to faktu, że z przykładu oka jako jednego z niezliczonej mnogości przedmiotów, których budowa musi nasunąć myśl o inteligentnej przyczynie, korzystał także Cyceroński Balbus (zobacz dz. cyt., s. 152-153). Proponowany powyżej „idealizm empiryczny”, wraz z wysnutym z niego powyżej wnioskiem teistycznym, zbliża się do „estetycznego teizmu” przypisywanego Hume'owi w pracy: J. Immerwahr, Hume's Aesthetic Theism, Hume Studies", vol. XXII, no. 2, 1996, s. 325-338, niemniej jednak nie jest z nim tożsamy i w mojej ocenie nieco bardziej odpowiada wyobrażeniu o „prawdziwym teizmie”, ewentualnie akceptowanym przez szkockiego filozofa.

${ }^{10}$ Jest ono również skonstruowane tak, aby już na wstępie uwzględniało Hume’owską analizę genezy przeświadczenia o istnieniu przedmiotów zewnętrznych oraz jego krytykę pojęcia związku przyczynowego, a zatem by nie stanowiły one natychmiastowego zarzutu, jaki mógłby zostać dodatkowo wysunięty przez sceptyka. Idąc za klasyczną interpretacją Dialogów, można przecież przypuszczać, że wyrazicielem stanowiska Hume’a jest Filon, a więc, że ta dialogowa postać otrzymałaby tego rodzaju wsparcie ze strony autora Traktatu. W sprawie tożsamości stanowiska Hume'a w Dialogach oraz Traktacie zob. D. Coleman, Interpreting Hume's „Dialogues”, „Religious Studies”, vol. 25, 1989, no. 2, s. 179-190. 
świata i mniema się, iż ma ona cechy analogicznie do cech posiadanych przez obserwowane przyczyny. Trudno odmówić racji sceptykowi, wskazującemu na dysproporcję między wycinkiem świata mieszczącym dzieła ludzkiej pomysłowości a pozostałym jego ogromem, dysproporcję niewątpliwie osłabiającą wniosek oparty na analogii. Nawet jeżeli dowolny organizm roślinny bądź zwierzęcy dostarcza dobitnego przykładu doskonale uporządkowanej całości, maszyny przewyższającej wszystko to, czego mógłby dokonać człowiek, to i tak analogia łączy ze sobą dwa rodzaje przedmiotów znajdujące się jedynie we fragmencie większej, nieobserwowanej całości. Natomiast w przypadku idealizmu empirycznego to niebezpieczeństwo wyraźnie się zmniejsza: na podstawie nie tego, co dzieje się w świecie zewnętrznym, którego istnienie nie jest wszelako stwierdzone przez idealistę empirycznego, a co najwyżej dopuszczone jako ewentualność, lecz w obrębie samych tylko wrażeń zmysłowych wnosimy o istnieniu czynnika duchowego, inteligencji, której istnienie głosi teizm empiryczny. Jednym słowem, istnienie świata materialnego, wraz z rozmaitością form materii, rozmaitością tak bardzo wedle sceptyka zagrażającą wnioskowi teistycznemu, wraz z akceptacją idealizmu staje się zaledwie teoretyczną możliwością, natomiast wniosek teistyczny z jawnie ryzykownego przekształca się w konkluzję, której ryzykowność jest co najwyżej możliwa. Argumentacji sceptyka odwołującej się do relacji między częścią a całością teista jest więc w stanie przeciwstawić kontrargument biorący pod uwagę nie mniej istotny stosunek możliwości do faktyczności - jeżeli świat zewnętrzny jest teoretycznie (to znaczy logicznie lub epistemicznie) możliwy, teoretycznie możliwa (a nie faktyczna) okaże się zasadność sceptycznego zarzutu niewspółmierności części i całości.

Niemniej niektóre $\mathrm{z}$ wysuniętych przezeń zarzutów pozostaną $\mathrm{w}$ mocy (w tym znaczeniu, że nadal wymagają odpowiedzi ze strony teisty). Po pierwsze bowiem, ze skończoności moich wrażeń niezależnych od woli, skończoności tak pod względem rodzaju, jak liczby, nadal nie wydaje się wynikać istnienie umysłu nieskończonego i najdoskonalszego. Po drugie, prawa analogii pozwalałyby sądzić w nawiązaniu do powyższej obserwacji, że tak jak niedoskonałe i ograniczone są nasze wybory dotyczące wrażeń zmysłowych, tak też wola i wybory owej postulowanej duchowej przyczyny musiałaby podlegać analogicznym niedoskonałościom i ograniczeniom. Jak poprzednio zatem, im ściślejsza analogia między naszym umysłem, podejmującym decyzje odnoszące się do przeżywanych wrażeń, a tym samym im lepiej uzasadniony empirycznie wniosek mówiący o istnieniu transcendentnego umysłu, tym mniej doskonałe, zmienne i chwiejne musiałyby go charaktery- 
zować postanowienia. Podobna zasada dotyczy oczywiście doświadczanego porządku - w przypadku wrażeń wydaje się on znacząco mniejszy aniżeli w przypadku przedmiotów materialnych - odpowiednio mniejsza musiałaby być inteligencja oraz doskonałość domniemanej przyczyny tam, gdzie nie sposób mówić o maszynach, czy o częściach, skutecznie spełniających taką czy inną funkcję. Po trzecie, jeżeli zgodzimy się na istnienie wielu podmiotów ujmujących wrażenia zmysłowe, analogię należałoby przeprowadzić dla każdego umysłu skończonego z osobna, a to nakazałoby stwierdzić istnienie wielu umysłów odpowiadających za wrażenia zmysłowe. Zachodziłaby wprawdzie możliwość przyjęcia założenia, że istnieje tylko jeden podmiot, odpowiadający za niezależne wrażenia we wszystkich umysłach skończonych, lecz tego rodzaju twierdzenie, będąc aprioryczną przesłanką a nie empirycznym wnioskiem, byłoby oczywiście tym bardziej wadliwe. Po czwarte, istnienie wrażeń przykrości i bólu, pojawiających się nierzadko w sposób nagły i nieprzewidziany, niejednokrotnie odznaczających się nie tylko wielką intensywnością, ale i znaczną trwałością, powinno w równym stopniu rodzić podejrzenia co do doskonałości owej domniemanej przyczyny.

Nietrudno jednakże odeprzeć zarzut T10), uzależniający zasadność rozumowania prowadzącego do uznania przyczyny świata od doświadczenia pokazującego wprawdzie, że światy podobne do naszego powstają w wyniku działania pewnego czynnika, ale leżącego poza zakresem naszych możliwości poznawczych. Sceptyk zgadza się na implikację niejako biegnącą od znanego nam świata do jego niematerialnej i doskonałej przyczyny pod warunkiem, że związek między tej postaci skutkiem a tego rodzaju przyczyną został ustalony w doświadczeniu; im więcej razy obserwowalibyśmy, że po akcie pewnego niematerialnego i doskonałego bytu powstaje materialny świat, tym bardziej byłby uprawniony wniosek, zgodnie z którym nasz świat stanowi dzieło niematerialnego umysłu, a skoro nie obserwowaliśmy takiej zależności nigdy, i świat, który nam się jawi, jest przedmiotem jednostkowym, nie należącym do rodzaju obserwowalnych rzeczy lub zjawisk, wniosek należy uznać za jawnie bezzasadny. Idealista empiryczny ma jednak prawo głosić, że jego wniosek jest empirycznie uprawniony. Skoro bowiem każda obserwowana przez nas przyczyna naszych wrażeń była tożsama z naszym aktem woli czy decyzją, wolno domniemywać, że przyczyna wrażeń nie będących naszym dziełem jest analogicznie podmiotem, jakkolwiek numerycznie różnym od nas. W rozumowaniu prowadzonym przez idealistę odpowiednikiem świata jako całości jest bowiem nie tyle umysł zawierający wrażenia udostępniane przez doświadczenie świadome, ile pojedyncze 
wrażenie zmysłowe, i jakkolwiek w doświadczeniu nie spostrzegliśmy korelacji między całością świata materialnego a jego doskonałą praprzyczyną, to przecież dowolne doświadczenie zmysłowe zależne od naszej woli czy postanowienia (chociażby w znaczeniu sprawstwa zaznaczonym powyżej) dostarcza poparcia dla tezy, że dowolne wrażenie, niezależne od nas analogicznie zależy od czyjejś woli bądź czyjegoś postanowienia. Filozof sceptyczny zapewne nie zgodzi się z przypuszczeniem, jakoby tego rodzaju odpowiednikiem świata mogło być pojedyncze wrażenie i wskaże, że to umysł jako całość stanowi analogon świata jako całości, inaczej bowiem analogia zachodzić będzie nie między podmiotem a przyczyną świata, ale między aktem woli i taką przyczyną. Nie widać jednakże powodu, dla którego teista nie mógłby się zgodzić na tego rodzaju porównanie, ma wszakże prawo powiedzieć, zdobywając się na swoisty nominalizm, że słowa oznaczające akty woli nie mają desygnatu różnego od słów oznaczających sam podmiot i że tylko pewien zwyczaj językowy nakazuje odróżniać „,akty woli” i „decyzje” od osoby, która chce lub decyduje.

Także zastrzeżenia uwzględnione w twierdzeniu T11) ulegną zasadniczemu osłabieniu wraz z przyjęciem tezy idealizmu empirycznego. Dzieje się tak przede wszystkim dlatego, że idealizm ten czyni z wrażeń przedmioty, których istnienie nie ulega zasadniczej wątpliwości, natomiast istnienie materii staje się przedmiotem naturalnej hipotezy. Ponownie zaznacza się różnica między tym, co stwierdzone, a tym, co jedynie dopuszczone bądź postulowane, a sceptyk nie powinien tej różnicy bagatelizować. Nie sposób tedy analogicznie przekonywać, że skoro nie znamy sposobu, w jaki wrażenia miałyby zależeć od umysłu, obdarzenie materii zdolnością do ich kształtowania byłoby hipotezą odznaczającą się większą prostotą. Zwolennikowi idealizmu wolno zresztą podać w wątpliwość ewentualną przesłankę sceptyka, czyli przypuszczenie, że nie znamy zasad kształtujących wrażenia zmysłowe - odpowie bowiem, że potrafimy je wykryć i że należą do nich, chociażby styczność oraz podobieństwo jak też to, co odbieramy jako związek przyczynowo-skutkowy. A zatem nie aprioryczna spekulacja, ale doświadczenie wskazuje, że wrażenia układają się zgodnie z tymi właśnie zasadami, a ponieważ nie wszystkie wrażenia zmysłowe pojawiające się w umyśle i zgodne z tymi zasadami są zależne od naszej woli, należy przyjąć istnienie analogicznego czynnika, a więc innego czynnika podmiotowego.

Niemniej jednak $\mathrm{w}$ stosunku do idealizmu empirycznego $\mathrm{z}$ łatwością można wysunąć trzy dodatkowe zarzuty, a mianowicie niemożliwości psychologicznej, antropocentryzmu oraz hipotetyzmu. Dwa pierwsze stanowią 
w istocie parafrazę krytyki zamieszczonej w samych Dialogach, a ściślej zastrzeżeń Kleantesa w stosunku do sceptycznej postawy zadeklarowanej przez Filona [I, 9-10, 14-16] oraz Demei odnośnie do stanowiska Kleantesa [III, 40-42], natomiast trzeci narzuca się sam przez się.

Zarzut psychologicznej niemożliwości głosi, że idealizm empiryczny stanowi niewystarczającą podstawę dla teizmu empirycznego, nawet nie z powodu wadliwości formalnej, lecz ze względu na fakt, że przeświadczenie to, jeżeli faktycznie kiedykolwiek pojawiłoby się w naszej świadomości, jak zakłada idealista, nie odznaczałoby się trwałością i wraz ze swoją podstawą musiałoby ustąpić miejsca postawie realistycznej ${ }^{11}$. „Religia naturalna” powinna zaś uzyskać podstawę nie tylko nienaganną metodologicznie, w postaci tez uzasadnionych ,naturalnie”, to znaczy bez odwołania do prawd objawionych, lecz także trwałą pod względem psychologicznym. Pod tym względem idealizm empiryczny wydaje się zbliżać do pirronizmu, który, jak w ostateczności stwierdza nawet sam Filon, a także autor Dialogów, nawet jeżeli zostanie uznany za trafny, nie zmieni naszych skłonności i nie wywrze większego wpływu na nasze przekonania i sposób postępowania. Nie uwa-

${ }^{11}$ Podstaw dla takiego zarzutu dostarcza np. filozofia T. Reida, wskazująca na naturalne i niezbywalne - jakkolwiek niekoniecznie logicznie usprawiedliwione - połączenie odbioru wrażeń zmysłowych z natychmiastowym i mimowolnym przekonaniem o istnieniu przedmiotu zewnętrznego, rozumianego jako przedmiot materialny. Interesujący musi się zatem wydać fakt, że w ten właśnie sposób tym razem Reid przeprowadzał pośrednią obronę tezy o istnieniu Boga, podważanej w jego przekonaniu przez wnioski wypływające $\mathrm{z}$,powszechnej teorii percepcji”. Oczywiście według Reida analiza tego połączenia, zwłaszcza myślowa separacja elementów złączonych może (a nawet, ze wspomnianych względów, powinna) dokonywać się ex post. Porównaj T. Reid, Rozważania o władzach poznawczych człowieka, przeł. M. Hempoliński, PWN, Warszawa 1975, zwłaszcza cz. II, rozdz. XVI, s. 240-250. W nawiązaniu do analiz Hume’owskich można by zapewne dodatkowo wysunąć utylitarystyczny kontrargument, wskazujący na moralną szkodliwość tego rodzaju praktyk czy doświadczeń, co najwyżej wykształcających w nas fałszywie pojmowane zalety, zwłaszcza te, które filozof ten określił pogardliwym mianem „cnót mnisich” (zob. D. Hume, Badania dotyczące zasad moralności, przeł. A. Hochfeld, PWN, Warszawa 1975, s. 122-123). Podejrzewam jednak, że wspomniana przeze mnie powyżej postawa nieco bardziej przypomina postawę kontemplacji estetycznej, której wartość, wzorem lorda Shaftesbury’ego, Hume niewątpliwie zauważał (zob. O wrażliwości smaku i uczuć, [w:] D. Hume, Eseje, s. 3-7). Treść tych przeżyć i przyjemność z nimi związana mogłyby zarazem stanowić pobudkę przyjmowania i ponawiania tej postawy, a w ten sposób pojawiłby się także motyw coraz bardziej skłaniający do uznania (teistycznego) wniosku, przemieniający ulotne przypuszczenie w przeświadczenie. Sadzę także, że można by do niej odnieść słowa Hume’a dotyczące prawdziwej religii: „Właściwe zadanie religii - to kierowanie sercem ludzkim, humanizacja obyczajów, wpajanie ducha umiarkowania, porządku i posłuszeństwa” [XII, 125]. 
żam jednak, by był to zarzut w pełni uprawniony. To bowiem, że postawa realistyczna dominuje w czasie trwania naszego życia i że przyjmujemy ją stale i mimowolnie, jeszcze nie oznacza, że chociażby chwilowy powrót do postawy idealistycznej nie jest w ogóle możliwy. Przeciwnie, wydaje się empirycznie możliwe wprowadzenie własnego umysłu w stan, w którym nasza bezpośrednia świadomość nie sięga poza wrażenia zmysłowe, przepływające przez nasze ,ja" oraz ponad towarzyszące im przekonanie, że tym wrażeniom mogą odpowiadać przedmioty zewnętrzne. Wzbudzanie w sobie takiego stanu mogłoby więc ożywiać i coraz mocniej utrwalać przekonanie o istnieniu duchowej przyczyny tych wrażeń, które odbieramy jako niezależne i uporządkowane w sposób przez nas nie zaplanowany. Można zatem powiedzieć, że wsparcia dla ,naturalnej religii” głoszącej istnienie transcendentnej przyczyny duchowej, dostarcza contemptus mundi (albo raczej contemptus materiae) w postaci swoistej praktycznej fenomenologii, którą jesteśmy w stanie uskuteczniać, nawet jeśli zwykle zachowujemy realistyczną postawę, polegającą na przeświadczeniu, że otacza nas rozmaitość przedmiotów nieożywionych oraz mnogość istot żywych. Co istotne, im częściej będziemy ją praktykować, tym bardziej uprawniona za sprawą doświadczenia - zgodnie z zasadami filozofii Hume'a - będzie ta hipoteza, a zarazem tym psychologicznie mocniejsze stawać się będzie przeświadczenie o jej prawdziwości ${ }^{12}$.

Zarzut antropocentryzmu wskazuje na uderzającą arbitralność rozumowania prowadzącego od uznania wrażeń istniejących niezależnie od czyjejś woli do wniosku stwierdzającego istnienie innego czynnika obdarzonego wolą. Nawet gdyby nasz umysł posiadał uprzywilejowany status pod względem poznawczym, to znaczy gdyby można było bez narażania się na sprzeczność przyjmować istnienie własnego umysłu oraz znajdujących się w nim wrażeń, nie uznając tezy o istnieniu przedmiotów zewnętrznych, nie

\footnotetext{
${ }^{12}$ Zwrócenie uwagi na możliwość uzależnionej od wewnętrznych lub zewnętrznych przyczyn niezdolności do tak rozumianej kontemplatywnej postawy, wydaje się uchylać ewentualny zarzut, jakiego nietrudno się dopatrzeć w następującej uwadze: „Wiara w istnienie niewidzialnej, rozumnej mocy rozprzestrzeniła się bardzo szeroko wśród ludów wszystkich ziem i czasów, ale nie jest to może wiara powszechna na tyle, ażeby nie dopuszczała wyjątków, a idee, jakie nasuwa, bynajmniej nie są jednolite. Jeżeli wierzyć podróżnikom i historykom, istnieją narody, które nie żywią żadnych zapatrywań religijnych; a nie ma w ogóle dwóch takich narodów, a zapewne i dwóch ludzi, których zapatrywania w tej kwestii byłyby zupełnie jednakowe. Wydawałoby się zatem, że to z góry narzucające się pojęcie nie pochodzi z pierwotnego instynktu czy też z pierwotnej impresji naturalnej [...]", Naturalna historia religii, dz. cyt., s. 139.
} 
oznaczałoby to wcale, że przyczyna całego świata, na który może przecież składać się mnogość przedmiotów materialnych (a takiej przyczyny dotyczy wniosek teistyczny) musi się znajdować w jakiejkolwiek analogii akurat do naszego umysłu oraz jego czynności i charakteryzować się czymś w rodzaju woli, decyzji albo inteligencji. Czym innym jest bowiem swoiste pierwszeństwo pod względem poznawczym, które w naszym przypadku charakteryzuje (niewykluczone) naszą własną jaźń oraz jej treści, które poznajemy zapewne najwcześniej i (być może) najpewniej, czym innym natomiast pierwszeństwo pod względem ontologicznym. Sądzę jednak, że idealista empiryczny ma jednak prawo odpowiedzieć na ten zarzut, iż sprowadza się on do tezy, że rozumowanie przez analogię, biegnące od umysłu i obecnych w nim wrażeń do istnienia innego czynnika duchowego, nie jest niezawodne. Możliwość błędu, którą idealista empiryczny zapewne bierze w rachubę, nie głosząc bynajmniej, że empiryczny teizm charakteryzuje się absolutną pewnością, nawet obiektywna możliwość, jest jednakże czymś innym niż faktycznie popełniony błąd. A zatem sam krytyk dopuszcza się uchybienia, utożsamiając ewentualność pomyłki z faktycznie popełnionym błędem.

Trzecie zastrzeżenie zasadza się na sugestii, że istnieje niezgodność między wnioskiem teistycznym a hipotezą realistyczną, stanowiącą element idealizmu empirycznego; hipoteza ta wszakże stwierdza, że przyczyną wrażeń niezależnych od naszej woli są przedmioty materialne, nazwane wcześniej ,zewnętrznymi”. Oznacza to, jak się wydaje, że jak długo uznajemy ów wniosek teistyczny wraz z jego podstawą, tak długo nie sposób zdobyć się na potwierdzenie hipotezy realistycznej (przynajmniej bez konsekwencji w postaci panteizmu), a zatem przedmioty zewnętrzne pozostają tylko i wyłącznie przedmiotami co najwyżej logicznie lub epistemicznie możliwymi. Nie wydaje się zaś, aby właściwe było rozumowanie, w którym wykazuje się istnienie Boga w sposób, który niejako bierze w nawias realność świata, wskazywałoby to bowiem niekoherencję przekonań dotyczących świata materialnego, skoro jedno z nich polegałoby na uznaniu ich możliwości i nie uznawaniu realności, natomiast drugie właśnie na takim uznaniu. Innymi słowy, musiałoby się okazać, że wniosek o istnieniu Boga jest zasadny tak długo, jak długo ni e uznajemy istnienia materii i traktujemy jej istnienie jako teoretyczną możliwość. Jakkolwiek i tego rodzaju zastrzeżenie skłonny byłbym uważać za przesadne, z całą pewnością idealista powinien wskazać sposób, w jaki można by pogodzić ze sobą idealizm empiryczny z empirycznym realizmem, tak aby nie zachodziła sprzeczność nie pozwalająca na racjonalne uznawanie obydwu przekonań i zapewne utrudniająca faktyczne 
ich uznawanie. Należy więc pogodzić tezę o Boskim sprawstwie wrażeń niezależnych od naszej woli, zamiaru czy decyzji, z naturalnym przeświadczeniem, że znajdujemy się w świecie przedmiotów materialnych, które działają na nasze zmysły. Naturalnym rozwiązaniem tej trudności, złączającym obydwie te koncepcje, byłoby, jak podejrzewam, stwierdzenie na zasadzie hipotezy, że istota analogiczna do naszego umysłu wywołuje w nas wrażenia zmysłowe za pośrednictwem oddziałujących na nas ciał. Związek przyczynowy przecież powinien stanowić relację przechodnią, przechodniość zaś nie pozbawia funkcji sprawstwa ani tego, co odgrywa rolę przyczyny bezpośredniej, ani tego, co miałoby lub mogłoby działać poprzez nią.

Idealizm empiryczny jest zatem w mniejszym stopniu niż realizm narażony na krytykę sformułowaną przez sceptyka Filona, jak również broni się przynajmniej przed najbardziej podstawowymi zarzutami, które można by dodatkowo wysunąć w stosunku do tego stanowiska. Wszystko to sprawia, że powinien być uznany za bardziej wartościową składową teizmu empirycznego niż stanowisko nazwane powyżej empirycznym realizmem i przypisane dialogowemu Kleantesowi.

\section{Bibliografia}

Berman D., A History of Atheism in Britain: From Hobbes to Russell, Routledge, London and New York 1988.

Capaldi N., Hume's Philosophy of Religion: God without Ethics, „International Journal for Philosophy of Religion", vol. 1, no. 4, 1970, s. 233-240.

Cicero M. T., O naturze bogów. O wróżbiarstwie. O przeznaczeniu, przeł. W. Kornatowski, PWN, Warszawa 1960.

Clarke S., A Demonstration of the Being and Attributes of God And Other Writings ed. by E. Vailati, Cambridge University Press, Cambridge 1998.

Coleman D., Interpreting Hume’s „Dialogues”, „Religious Studies”, vol. 25, no. 2, 1989, s. $179-190$.

Cooper A. A., third earl of Shaftesbury, Characteristics of Men, Manners, Opinions, Times, ed. by L. E. Klein, Cambridge University Press, Cambridge 2000.

Cordry B. S., A more dangerous enemy? Philo's "confession" and Hume's soft atheism, „International Journal for Philosophy of Religion”, vol. 70, no. 1, 2011, s. 61-83.

Gaskin J. C. A., Hume on Religion, [w:] Norton D. F., Taylor J. (eds.), The Cambridge Companion to Hume, Cambridge University Press, Cambridge 2008, s. 480-513. Hume D., Badania dotyczace rozumu ludzkiego, przeł. J. Łukasiewicz i K. Twardowski, PWN, Warszawa 1977. 
Hume D., Badania dotyczące zasad moralności, przeł. A. Hochfeld, PWN, Warszawa 1975.

Hume D., Dialogi o religii naturalnej. Naturalna historia religii wraz $z$ dodatkami, przeł. A. Hochfeldowa, PWN, Warszawa 1962.

Hume D., Dialogues concerning Natural Religion and Other Writings, ed. by D. Coleman, Cambridge University Press, Cambridge 2007.

Hume D., Eseje z dziedziny moralności i literatury, przeł. T. Tatarkiewiczowa, PWN, Warszawa 1955.

Hume D., Traktat o naturze ludzkiej, przeł. Cz. Znamierowski, Fundacja Aletheia, Warszawa 2005.

Hurlbutt R. H., David Hume and Scientific Theism, "The Journal of the History of Ideas", vol. 17, no. 4, 1956, s. 486-497.

Immerwahr J., Hume's Aesthetic Theism, „Hume Studies”, vol. XXII, no. 2, 1996, s. $325-338$.

Johnson C., Joseph Butler, Laodicean Rationalist?, „Modern Language Studies”, vol. 4, no. 2,1974 , s. $78-85$.

Kant I., Krytyka czystego rozumu, przeł. R. Ingarden, Wydawnictwo Antyk, Kęty 2001.

Kołakowski L., Filozofia pozytywistyczna. (Od Hume’a do Koła Wiedeńskiego), PWN, Warszawa 1966.

Locke J., Rozważania dotyczące rozumu ludzkiego, t. 2, przeł. B. Gawecki, PWN, Warszawa 1955.

Logan B., Why Hume Wasn't an Atheist: A Reply to Andre, „Hume Studies”, vol. XXII, no. 1, 1996, s. 193-202.

Manning R. J. S., David Hume's „Dialogues Concerning Natural Religion”: Otherness in History and Text, „Religious Studies”, vol. 26, no. 3, 1990, s. 415-426.

Merrill K. R., Historical Dictionary of Hume's Philosophy, The Scarecrow Press, Inc., Lanham, Toronto, Plymouth 2008.

Mossner E. C., The Enigma of Hume, „Mind”, vol. 45, no. 179, 1936, s. 334-349.

Mossner E. C., The Religion of David Hume”, „The Journal of the History of Ideas”, vol. 39 , no. 4,1978 , s. 563-663.

Noxon J., Hume's Agnosticism, „The Philosophical Review”, vol. 73, no. 2, 1964, s. $248-261$.

O'Connor D., Routledge Philosophy Guide Book to Hume on Religion, Routledge, London and New York 2001.

Penelhum T., God and Scepticism, D. Riedl Publishing Company, Dordrecht 1983.

Price J. V., Empirical Theists in Cicero and Hume, „Texas Studies in Literature and Language", vol. 5, no. 2, 1963, s. 255-264.

Price J. V., Sceptics in Cicero and Hume, „The Journal of the History of Ideas”, vol. 25, no. 1, 1964, s. 97-106. 
Reid T., Rozważania o władzach poznawczych człowieka, przeł. M. Hempoliński, PWN, Warszawa 1975.

Rivers I., Reason, Grace, and Sentiment. A study of the language of religion and ethics in England 1660-1780, vol. II: Shaftesbury to Hume, Cambridge University Press, Cambridge 2000.

Sessions W. L., Reading Hume's Dialogues: A Veneration of True Religion, Indiana University Press, Bloomington and Indianapolis 2002.

Sprague E., Hume, Henry More and the Design Argument, „Hume Studies”, vol. XIV, no. 2,1988 , s. 305-327.

Swinburne R., The Argument from Design, „Philosophy”, vol. 43, no. 165, 1968, s. 199-212.

Swinburne R., The Existence of God, Clarendon Press, Oxford 2004.

Tweyman S., Scepticism and Belief in Hume's Dialogues Concerning Natural Religion, Martinus Nijhoff Publishers, Dordrecht 1986.

White D. E. (ed.), The Works of Bishop Butler, University of Rochester Press, Rochester 2006.

\section{Abstract \\ On "experimental theism" in David Hume's Dialogues Concerning Natural Religion}

In this article I shall attempt to constrain David Hume's profound attack on "experimental theism" (famously advocated in the Dialogues by Cleanthes), by a) making a distinction between "experimental realism", which, as I shall argue, can be equated with Cleanthes' justification of (experimental) theism, and subtly different "experimental idealism", which, importantly, as an alternative standpoint seems to raise no additional difficulty, and b) showing that "experimental theism", provided it is associable also with the latter, turns out in fact to be immune to a part of Hume's criticism of the former.

Key words: experimental theism, empirical theism, David Hume's Dialogues Concerning Natural Religion 